\title{
Academic Challenges of Female Graduate TESOL Students in the Saudi Context
}

\author{
Boushra Alghamdi (Corresponding author) \\ English Language Institute, Jeddah University \\ E-mail: Balghamdi@uj.edu.sa \\ Nada Alasmari \\ King Abdulaziz University \\ Dr. Nadia Shukri \\ King Abdulaziz University, Jeddah
}

$\begin{array}{lc}\text { Received: November 5, } 2019 & \text { Accepted: November 20, } 2019 \quad \text { Published: November 24, } 2019 \\ \text { doi:10.5296/ijele.v8i1.15902 } & \text { URL: https://doi.org/10.5296/ijele.v8i1.15902 }\end{array}$

\begin{abstract}
Academic challenges are apparent factors that might hinder the progress and efficiency of students' higher education. Moreover, identifying these challenges will contribute to the progress of academic programs as well as maximizing academic achievement. The current research aims to shed the light on the various academic challenges that graduate female students majoring in Teaching English to Speakers of Other Languages (TESOL) encounter in the Saudi context. Furthermore, the current study serves to expand the knowledge about the most prominent academic challenges that TESOL students experience in the given context. Thus, helping students overcome these issues which might result in better performance and more qualified students. In addition, this study follows a mixed method research; and the participants are 23 Saudi female TESOL students. The study employed a questionnaire adapted from Phakiti and Li's (2011); the questionnaire consisted of 4 sections that include 24 close-ended question, in addition to 2 open-ended questions. The results of this study reveal three leading areas of academic challenges that TESOL students experience in their academic studies. The most prominent area of difficulty is academic writing, academic reading, and lastly other general academic challenges such as speaking skills and managing the academic load. The findings of this study reveal that female TESOL students encounter several challenges and obstacles that hinder their academic success. Also, recommendations for further research are mentioned to investigate the factors causing these academic challenges.
\end{abstract}

Keywords: Academic challenges, TESOL learners 


\section{Introduction}

Being a postgraduate student means, among other things, joining Academia and becoming a researcher. Nowadays, with millions of learners holding master's degrees and plenty of publications on their resume, the pressure of being an excellent and effective postgraduate student may be demanding. To enhance learners' academic performance, they need to identify and overcome any lacks or challenges they encounter. In order to achieve that, a needs analysis should be given to the students, in addition, the program designers should examine its results. According to Richards (2001), "what is identified as a need is dependent on judgment and reflects the interests and values of those making such a judgment" (p. 54). Needs analysis is an investigation of learners' current level of knowledge and the level they aspire to reach (Nation \& Macalister, 2009).

Various researchers have examined the challenges that higher education students encounter (Fung, Southcott, \& Siu, 2017; Hyland, 2016; Llurda, 2005; Thunborg, Merrill, \& Finnegan, 2014). However, there is a lack of studies regarding the challenges TESOL students come across in their academic studies, particularly in the Saudi context. Therefore, this study aims to investigate female Saudi postgraduate students' perceptions of the general academic challenges they face. Thus, helping the program's designers in distinguishing the students' needs in order to provide them with support and various workshops, which would result in more accomplishing and qualified students. The study's sample is from the female section of TESOL master's program at King Abdul-Aziz University in Jeddah. The research question is: what are the most challenging academic skills that need to be acquired, according to female Saudi TESOL master's program students? To answer this question, a questionnaire was adapted from Phaikiti and $\mathrm{Li} \mathrm{(2011)} \mathrm{and} \mathrm{modified} \mathrm{to} \mathrm{suit} \mathrm{the} \mathrm{aims} \mathrm{of} \mathrm{the} \mathrm{study,} \mathrm{in} \mathrm{addition} \mathrm{to}$ two open-ended items.

\subsection{The TESOL Graduate Program}

The MA program presented at King Abdul-Aziz university is of two years, three semesters of courses and one semester for writing the thesis. There are 9 courses that students are required to pass, 7 of them are mandatory and 2 of them are eclectic. Some of the courses given in the program are Second Language Acquisition Theories, Research Methods, and Language Curriculum Design. As MA students, learners of the program are required to participate in discussions about the books' material and additional required academic articles and seminal works of the field, also they are required to give oral presentations, write academic critiques and write various research papers. Therefore, proving to be capable of such heavy demands is not an easy task for students and the anxiety they feel under pressure make their academic lacks even worse.

\section{Literature Review}

To date, most of the research conducted regarding non-native TESOL students revolve around difficulties they face while studying in an English-speaking country (Lee \& Lew, 2001; Phakiti $\& \mathrm{Li}, 2011$ ) or around academic writing difficulties (Al Fadda, 2012; AlHashmi, AlSubaeie, \& 
Shukri, 2017). However, studies on non-native TESOL postgraduate students' perceived general academic challenges are lacking, especially in the Saudi context where English is a foreign language $(\mathrm{FL})$.

When it comes to non-native TESOL students studying abroad, challenges such as anxiety and sense of inferiority (Lee \& Lew, 2001) and difficulties in academic reading and writing (Braine, 1999; Phakiti \& Li, 2011) were reported. In the study done by Lee and Lew (2001), they collected their data through written diaries and interviews to examine the feelings of non-native speakers (NNS) of English in an English-speaking country. Their sample consisted of four NNSs enrolled in a postgraduates program in TESOL in the United States of America. Their findings show that NNSs feel anxiety the most while writing, reading, and speaking in English, which results in feelings of inferiority around their native English-speaking peers. Phakiti and $\mathrm{Li}$ (2011) decided to examine the general academic difficulties faced by Asian students in an Australian context through a mixed method research: 51 participants answered a Likert scale questionnaire and then 11 of the sample were interviewed for a deeper understanding of the topic. Similar to the results found by Lee and Lew (2001), these participants faced major difficulties when it came to academic reading and writing. In addition, Phakiti and Li (2011) reported that the difficulties found were also related, for example, facing challenges in academic reading would affect their academic writing because each medium is used mainly to represent their understanding of the other. The current study adopted the survey made by Phaikiti and Li (2011); however, unlike their study, the present study aims to examine general academic challenges faced by NNS TESOL (non-native speakers studying TESOL) students in their home country.

\subsection{Academic Writing}

It seems evident from the studies mentioned above that academic reading and writing is a common problem among NNS learners studying abroad, so it is only realistic that most studies conducted in Asian and Arab countries about TESOL students are focusing on these two factors. AlHashmi, AlSubaeie, and Shukri (2017), using a questionnaire to find out the academic writing needs of female Saudi TESOL students and their instructors, reported a slight discrepancy between the perceptions of the two parties. On one hand, the students ranked general academic writing abilities and adequate presentation of written ideas as the most needed academic writing skills. On the other hand, their instructors believe that punctuation and other grammatical aspects are essential. According to AlFadda (2012), one of the issues that a sample of 50 graduate students majoring in English as a Second Language (ESL) face in academic writing is "distinguishing between spoken and written styles in English texts" (p. 127).

\subsection{Academic Reading}

Academic reading is a significant skill that affects students' success in their academic studies. In addition, students often face challenges in reading academic texts due to the importance of these texts along with their unfamiliarity with the use of academic reading skills (Dhieb-Henia, 2003). One of these challenges is drawing conclusions and making inferences, as Gönen (2015) found when exploring the difficulties that FL readers face when reading academic 
materials. He found out that students often faced difficulties in identifying main ideas and differentiating important ideas from unimportant ones; in addition, they found inferring information from academic texts highly challenging. Gönen also stated that students found it challenging to draw conclusions while reading, and he related these challenges to the fact that some students were not aware of the correct use of academic reading skills and strategies. Zhao (2015) believes that students' understanding of synthesis and their ability to manage sources of reading have a significant impact on their ability to do academic reading successfully. In his study, Zhao studied two students' academic experience and their own understanding of the nature of synthesis and reading sources, and he reported that the unsuccessful readers exhibited difficulties in synthesizing information as well as making connections and finding relevant sources while reading. Similarly, Boakye (2017) in her research examined the specific nature of reading challenges, and she found that students faced difficulties in extracting and synthesizing of the reading text. According to Meniado (2016), investigating Saudi students' comprehension performance and reading strategies, reported that students sometimes face difficulties in reading comprehension and analyzing the ideas of the read text.

\subsection{Other Academic Challenges}

Regarding other areas that pose a challenge for students' academic studies, coping with academic load has a significant impact on academic success. According to Mahmood and Burke (2018), there is a direct relation between stress levels and a student's ability to adapt to varying academic load; in addition, students who could not adapt found their academic performance negatively affected. Similarly, Turkpour, and Mehdinezhad (2016) emphasized the role of adapting to one's academic load and its effect on college students performance; furthermore, they linked students' ability to deal with academic work to the availability of academic support. Another area that is challenging for students is the use of educational applications and software and online study. Yu and Richardson (2015) explored students' readiness for online learning and they found that it has important relation to technical competency; therefore, low technical competence will result in low online learning readiness. Kuama (2016) argue that students' online learning ability and success depends on their correct use of online learning strategies; in addition, there are students who face difficulties in using online study due to a lack of knowledge about the correct online learning strategies to use. Al-Azawei, Parslow, and Lundqvist (2016) investigated e-learning implementation amongst university students and found that most students faced several challenges that hinder the correct implementation of e-learning and e-learning technologies, some of which are external, others internal. Other academic difficulties that students might experience while pursuing their academic studies include oral presentation skills (Al-Issa \& Al-Qubtan, 2010; Sukitkanaporn \& Phoocharoensil, 2014) and academic speaking skills (Al-Jamal \& Al-Jamal, 2013; Pittenger, Miller, \& Mott, 2004; Sawir 2005).

\section{Research Questions}

The current study attempts to answer the following questions: 


\section{$\Lambda$ Macrothink}

1. What are the academic challenges female Saudi TESOL students faces?

2. What are the most challenging academic skills according to Saudi female students?

\section{The Methodology}

By following a mixed research method, the current study aims to find the general academic challenges or difficulties female Saudi post-graduate students face while completing their master's degree in TESOL. In addition, which academic skill is most challenging for them?

\subsection{Participants}

The targeted sample was 23 female Saudi post-graduate students enrolled in an MA program in TESOL at KAU, located in Jeddah, KSA. The study followed a purposive sampling method where participants are chosen due to their qualities that matches the aim of the study (Etikan, Musa, \& Alkassim, 2016). The survey that the study applied contained a section about learners' background information, asking about their age, and their test scores for TOEFL and the International English Language Testing System (IELTS) to check their English proficiency levels, and lastly, their grade point average (GPA). This information was thought to help in finding a relation between learner's level of proficiency and the type of academic difficulties they faced. From the data collected, it could be seen that the learners' ages varied from 20 to 50 years old, with $50 \%$ of them between 25 and 30 . As for their IELTS or TOFEL scores, most of the participants scored 6 and above on their IELTS exam because it was the required score for acceptance in the TESOL master's program. However, two participants took the TOFEL exam instead and scored 89, and 91 out of 120 . Figure 1 below shows the IELTS scores in more detail.

Table 1. Participants and their IELTS scores

\begin{tabular}{|l|l|}
\hline IELTS score & Number of participants \\
\hline 6 & 5 \\
\hline 6.5 & 7 \\
\hline 7 & 6 \\
\hline 7.5 & 1 \\
\hline 8 & 2 \\
\hline
\end{tabular}

From these data, it was evident that the participants were of high intermediate to advanced levels of proficiency in the English language and were capable of handling complex linguistic structures in that language (Takeielts.britishcouncil.org, 2018).

\subsection{Procedure}

After signing an approval form from the institution to proceed with distributing the questionnaire, the researchers created a Google Form to write the survey and contacted the 
female TESOL students to fill out the survey online. The data collected were analyzed via SPSS software and thematic analysis.

\subsection{Instrument}

To collect the quantitative data, this paper implemented a modified version of Phakiti and Li's (2011) questionnaire. The survey consisted of 4 sections, and a total of 24 items and 2 open ended questions. To answer the questions participants had to choose from 5 Likert scale items ranging from strongly agree $=5$, agree $=4$, undecided $=3$, disagree $=2$, to strongly disagree $=1$. The first section of the survey was asking for some background information, as discussed in the sample section above. The second section began with the statement 'While I am studying, I find it difficult to...' followed by a list of general academic skills, such as doing formal presentations and e-learning, and learners had to choose from the Likert scale. The third section was for academic reading and asked about the degree of difficulty of certain reading skills, such as skimming, and comparing ideas. The last section was about academic writing skills, such as writing clear and direct pieces and writing qualitative and quantitative research. The last section of the questionnaire involved two open-ended questions asking which of the skills posed in the questionnaire causes the greatest challenge and what other academic difficulties the learners faced. This study's emphasis is on academic reading and writing mainly because of their complexity and because their challenging nature is common among ESL/FL speakers (Lee \& Lew, 2001; Phakiti \& Li, 2011); however, other academic challenges were also discussed.

\subsection{Reliability and Validity}

To ensure the reliability of the questionnaire, a reliability test was executed through SPSS and the result of Cronbach Alpha was .873, which means that the survey's items are consistent and reliable (Dornyei, 2007). As for the validity, the questionnaire had already been used in the work of Phakiti and $\mathrm{Li}$ (2011) and the modifications to it were done under the consultation and supervision of a TESOL expert.

\section{Data Analysis}

\subsection{Quantitative Data}

The presentation of results will be as follows: the results are displayed in the tables below and an explanation of their content is presented beforehand in each case. The tables contain the frequency, which means the number of participants choosing a certain Likert scale point and the percentages of these choices. The displaying of the various sections is in the same sequence as that in which they appeared to the participants in the questionnaire. The general academic challenges are presented first, then the academic reading challenges and academic writing challenges. In addition, while explaining the results, answers of the same nature are combined together (e.g., "strongly agree" and "agree" together).

\subsubsection{General Academic Challenges}




\section{MInstitute ${ }_{\text {Intm }}^{\text {Macrothink }}$}

This section consists of 10 items, and of the items that TESOL students reported having difficulties with, academic writing came at the top, followed by academic reading and speaking. The majority of the participants $(69.6 \%)$ agreed that academic writing is the most challenging aspect of their academic studies. Coming in the second place of skills that the participants find challenging, are academic reading and academic speaking (both at 56.5\%). On the other hand, the majority of the participants $(60.8 \%)$ did not find learning independently a challenging task. Other items, such as feeling comfortable with the academic load, are not that clear-cut: $47.8 \%$ of the participants said that it is a challenging aspect, $34.8 \%$ believed it was not, and $17.4 \%$ were uncertain. However, there is a general tendency among participants towards agreeing that most of the activities referred to in these statements pose a challenge for them, except for items 4,7 , and 9, which refer to academic listening, e-learning, and using educational technological applications.

Table 2. General academic challenges

\begin{tabular}{|c|c|c|c|c|c|}
\hline \multirow{2}{*}{$\begin{array}{l}\text { The questionnaire } \\
\text { items } \\
\text { * While I am } \\
\text { studying, I find it } \\
\text { difficult to: }\end{array}$} & \multicolumn{5}{|c|}{ Percentages of participants' answers } \\
\hline & $\begin{array}{l}\text { Strongly } \\
\text { agree }\end{array}$ & Agree & Undecided & Disagree & $\begin{array}{l}\text { Strongly } \\
\text { disagree }\end{array}$ \\
\hline $\begin{array}{ll}1- & \text { Learn } \\
\text { independently } & \end{array}$ & $0 \%$ & $21.7 \%$ & $17.4 \%$ & $39.1 \%$ & $21.7 \%$ \\
\hline $\begin{array}{l}\text { 2- Feel comfortable } \\
\text { with the academic } \\
\text { load }\end{array}$ & $8.7 \%$ & $39.1 \%$ & $17.4 \%$ & $17.4 \%$ & $17.4 \%$ \\
\hline $\begin{array}{l}3-\quad \text { Do academic } \\
\text { reading }\end{array}$ & $30.4 \%$ & $26.1 \%$ & $0 \%$ & $34.8 \%$ & $8.7 \%$ \\
\hline \multirow{2}{*}{$\begin{array}{l}\text { The questionnaire } \\
\text { items } \\
\text { * While I am } \\
\text { studying, I find it } \\
\text { difficult to: }\end{array}$} & \multicolumn{5}{|c|}{ Percentages of participants' answers } \\
\hline & $\begin{array}{l}\text { Strongly } \\
\text { agree }\end{array}$ & Agree & Undecided & Disagree & $\begin{array}{l}\text { Strongly } \\
\text { disagree }\end{array}$ \\
\hline $\begin{array}{l}\text { 4- Do academic } \\
\text { listening }\end{array}$ & $13 \%$ & $21.7 \%$ & $17.4 \%$ & $39.1 \%$ & $8.7 \%$ \\
\hline $\begin{array}{l}5-\quad \text { Do academic } \\
\text { writing }\end{array}$ & $34.8 \%$ & $34.8 \%$ & $8.7 \%$ & $4.3 \%$ & $17.4 \%$ \\
\hline
\end{tabular}




\begin{tabular}{|l|l|l|l|l|l|}
\hline $\begin{array}{l}\text { 6- Do academic } \\
\text { speaking }\end{array}$ & $26.1 \%$ & $30.4 \%$ & $13 \%$ & $17.4 \%$ & $13 \%$ \\
\hline 7- Use e-learning & $21.7 \%$ & $21.7 \%$ & $0 \%$ & $34.8 \%$ & $21.7 \%$ \\
\hline $\begin{array}{l}\text { 8- Do formal } \\
\text { presentations }\end{array}$ & $13 \%$ & $26.1 \%$ & $8.7 \%$ & $39.1 \%$ & $13 \%$ \\
\hline $\begin{array}{l}\text { 9- Use educational } \\
\text { applications and } \\
\text { technology }\end{array}$ & $13 \%$ & $26.1 \%$ & $13 \%$ & $21.7 \%$ & $26.1 \%$ \\
\hline $\begin{array}{l}\text { 10- Do self-study on } \\
\text { the internet }\end{array}$ & $21.7 \%$ & $26.1 \%$ & $17.4 \%$ & $26.1 \%$ & $8.7 \%$ \\
\hline
\end{tabular}

\subsubsection{Challenges of Academic Reading}

In this section, 6 items ask about the degree of challenge of academic reading-related issues, such as comparing, contrasting, and skimming. The majority of participants (73.9\%) agreed that analyzing the ideas and understanding the implications of an academic text together with synthesizing information from alternative sources of reading text are the most challenging aspects of academic. A majority (69.6\%) also reported their struggle with comparing and contrasting ideas of texts and using these texts for future reference.

Table 3. Academic reading challenges

\begin{tabular}{|l|l|l|l|l|l|}
\hline $\begin{array}{l}\text { The questionnaire } \\
\text { items }\end{array}$ & \multicolumn{3}{|l|}{ Percentages of participants' answers } \\
\cline { 2 - 6 } $\begin{array}{l}\text { While I am } \\
\text { reading, I find it } \\
\text { difficult to: }\end{array}$ & $\begin{array}{l}\text { Strongly } \\
\text { agree }\end{array}$ & Agree & Undecided & Disagree & $\begin{array}{l}\text { Strongly } \\
\text { disagree }\end{array}$ \\
\hline $\begin{array}{l}11-\text { Search for } \\
\text { alternative sources } \\
\text { of reading texts }\end{array}$ & $17.4 \%$ & $56.5 \%$ & $17.4 \%$ & $4.3 \%$ & $4.3 \%$ \\
\hline $\begin{array}{l}12-\text { Skim and scan } \\
\text { in order to read } \\
\text { more texts }\end{array}$ & $13 \%$ & $52.2 \%$ & 0 & $34.8 \%$ & 0 \\
\hline $\begin{array}{l}13-\text { Compare and } \\
\text { contrast ideas }\end{array}$ & $8.7 \%$ & $60.9 \%$ & $4.3 \%$ & $26.1 \%$ & 0 \\
\hline $\begin{array}{l}14-\text { Determine the } \\
\text { main idea or }\end{array}$ & $13 \%$ & $39.1 \%$ & $8.7 \%$ & $34.8 \%$ & $4.3 \%$ \\
\hline
\end{tabular}




\begin{tabular}{|l|l|l|l|l|l|}
\hline $\begin{array}{l}\text { aspects of a } \\
\text { passage }\end{array}$ & & & & \\
\hline $\begin{array}{l}15-\text { Analyze ideas } \\
\text { and identify } \\
\text { implications of the } \\
\text { reading }\end{array}$ & $56.4 \%$ & $56.5 \%$ & $17.4 \%$ & $8.7 \%$ & 0 \\
\hline $\begin{array}{l}16-\text { Remember } \\
\text { major ideas for } \\
\text { later or for future } \\
\text { use or reference }\end{array}$ & $21.7 \%$ & $47.8 \%$ & $8.7 \%$ & $17.4 \%$ & $4.3 \%$ \\
\hline
\end{tabular}

\subsubsection{Challenges of Academic Writing}

While the participants chose the academic writing as the most challenging requirement of the TESOL program, they also generally agreed on the difficulty of most of the statements mentioned. However, scoring the highest percentage among the items was item number 19, which states that it is difficult to use relevant sources to back up arguments and support ideas, to which $73.9 \%$ of the participants agreed. Also, $69.6 \%$ agreed with items 17, 21, and 22, which refer, respectively, to difficulty in finding relevant resources (i.e., literature review), difficulty writing a sufficient piece while following the guidelines of various assignments, and difficulty organizing ideas comprehensively.

Table 4. Academic writing challenges

\begin{tabular}{|c|c|c|c|c|c|}
\hline \multirow{2}{*}{$\begin{array}{l}\text { The questionnaire } \\
\text { items } \\
\text { *When I write in } \\
\text { order to learn and } \\
\text { fulfill course } \\
\text { requirements, I } \\
\text { find it difficult to: }\end{array}$} & \multicolumn{5}{|c|}{ Percentages of participants' answers } \\
\hline & $\begin{array}{l}\text { Strongly } \\
\text { agree }\end{array}$ & Agree & Undecided & Disagree & $\begin{array}{l}\text { Strongly } \\
\text { disagree }\end{array}$ \\
\hline $\begin{array}{l}\text { 17- Extensively } \\
\text { search for } \\
\text { relevant sources } \\
\text { of information for } \\
\text { assignments }\end{array}$ & $43.5 \%$ & $26.1 \%$ & $8.7 \%$ & $21.7 \%$ & 0 \\
\hline $\begin{array}{l}\text { 18- Understand } \\
\text { the expectations } \\
\text { of the assignment }\end{array}$ & $26.1 \%$ & $30.4 \%$ & $26.1 \%$ & $13 \% 4.3 \%$ & $4.3 \%$ \\
\hline
\end{tabular}




\begin{tabular}{|l|l|l|l|l|l|}
\hline $\begin{array}{l}\text { 19- Use relevant } \\
\text { reasons and } \\
\text { examples to } \\
\text { support ideas }\end{array}$ & $60.9 \%$ & $8.7 \%$ & $13 \%$ & $4.3 \%$ \\
\hline $\begin{array}{l}\text { 20- Learn how to } \\
\text { write straightly to } \\
\text { the point }\end{array}$ & $8.7 \%$ & $52.2 \%$ & $8.7 \%$ & $26.1 \%$ & $4.3 \%$ \\
\hline $\begin{array}{l}\text { 21- Produce } \\
\text { sufficient quantity } \\
\text { and quality of } \\
\text { written text while } \\
\text { following the } \\
\text { assignment } \\
\text { requirements }\end{array}$ & $6.7 \%$ & $60.9 \%$ & 0 & $30.4 \%$ & 0 \\
\hline $\begin{array}{l}22-\text { Organize my } \\
\text { writing to meet } \\
\text { expected } \\
\text { academic writing } \\
\text { styles }\end{array}$ & $17.4 \%$ & $52.2 \%$ & $17.4 \%$ & $8.7 \%$ & $4.3 \%$ \\
\hline $\begin{array}{l}23-\text { Do APA } \\
\text { citations, } \\
\text { quotations, } \\
\text { references }\end{array}$ & $34.8 \%$ & $4.3 \%$ & $26.1 \%$ & $21.7 \%$ \\
\hline $\begin{array}{l}24-\text { avid } \\
\text { plagiarism }\end{array}$ & $30.4 \%$ & $13 \%$ & $13 \%$ & $26.1 \%$ \\
\hline
\end{tabular}

\subsection{Qualitative Data}

The qualitative data included two questions, the first of which asks which areas mentioned in the closed-ended items above the participants find most challenging.

Table 5. Challenges students faced

\begin{tabular}{|l|l|l|}
\hline Writing challenges & Reading challenges & General academic challenges \\
\hline $15(65.22 \%)$ & $5(21.77 \%)$ & $3(13.4 \%)$ \\
\hline
\end{tabular}

Table 5 results indicate that 15 participants believed that academic writing is the most challenging area mentioned in the closed-ended section of the survey, whereas 5 participants 
found academic reading is the most challenging, and only 3 participants reported that general academic challenges are the most difficult.

The second question asks what other academic challenges the students face. Only 2 participants mentioned using SPSS and EndNote software, 1 participant mentioned group work, and 1 mentioned meeting deadlines. The rest of the answers submitted by the participants are mostly the same areas of difficulties mentioned in the closed-ended questions such as challenges with academic writing, reading and comprehending academic articles, and academic presentation.

\section{Discussion}

The leading goal of this study is to determine the difficulties and challenges that Saudi female TESOL students face in their academic studies. The findings of the current study illustrate mainly three dominant areas of difficulty that Saudi female TESOL students experience. The first and most prominent is academic writing difficulties; the results show that most of the students reported that they find it rather challenging to do academic writing, which aligns with what AlHashmi, AlSubaeie, and Shukri (2017) and AlFadda (2012) reported about students' academic writing difficulties and needs. The second area of difficulty reported in this study is academic reading challenges. The results show that students face several difficulties regarding academic reading, such as searching for alternative sources for the reading text, comparing and contrasting ideas, and analyzing ideas. This goes hand in hand with what Boakye (2017), Gönen (2015), Meniado (2016), and Zaho (2015) claimed about reading challenges.

Regarding general and other academic challenges, the findings of the current study indicate that students do not face challenges related to e-learning and using educational applications, which contradicts findings by Al-Azawei, Parslow, and Lundqvist (2016), Kuama (2016), and $\mathrm{Yu}$ and Richardson (2015). Another finding is that adapting to academic load and dealing with pressure are challenging aspects of academic studies, and this finding corresponds with those of Mahmood and Burke (2018) and Turkpour and Mehdinezhad (2016). In addition, this study also points out that students find oral presentations and discussing academic journals with their peers and instructors rather challenging, which corresponds with the findings by Al-Jamal \& Al-Jamal (2013), Pittenger, Miller, \& Mott (2004), and Sawir (2005).

\section{Conclusion}

In conclusion, this study aims to explore academic challenges faced by female TESOL students in the Saudi context; in addition, it aims to identify the most prominent area of difficulty. In order to fulfill these aims, the study followed a mixed paradigm; in addition, the participants in this study were 23 female TESOL students. Furthermore, the findings of this study indicate that there are three leading academic areas that students' find challenging. 


\section{Ml Macrothink}

These areas include academic writing, academic reading, and general academic challenges such as adapting to academic load and oral presentation skills.

Having the knowledge of these academic challenges that might hinder academic progress will help both policy-makers and teachers provide solutions and programs that help students to further their academic studies.

\section{Limitation of the Study}

One limitation of this study might be the difficulty in accessing a larger number of participants, since the number of TESOL students is relatively limited. In addition, the study could be more generalizable if there were interviews conducted with the participants to have a richer qualitative data. Moreover, there were time constraints due to the participants' busy academic life, which contributed to the delay in submitting the questionnaire answers.

\section{Recommendations}

The current study focuses on exploring the academic challenges of TESOL female students. However, further research into the reasons leading to the occurrence of academic challenges is recommended, which will help policy makers along with teachers to improve the TESOL master program. In addition, incorporating a larger number of participants would be beneficial, to capture a richer field of data. Moreover, an in-depth investigation of academic reading challenges, as well as academic writing challenges in the Saudi context, is recommended, to help Saudi TESOL students overcome these difficulties and achieve desirable goals. Finally, the results of this paper, if taken seriously, could prompt the MA program administrators to establish an academic writing center and hire experienced academics to assess students with their studies and give them any necessary advices.

\section{References}

Al-Azawei, A., Parslow, P., \& Lundqvist, K. (2016). Barriers and opportunities of e-Learning implementation in Iraq: A case of public universities. The International Review of Research in Open and Distributed Learning, 17(5).

Al-Issa, A. S., \& Al-Qubtan, R. (2010). Taking the floor: Oral presentations in EFL classrooms. TESOL Journal, 1(2), 227-246. https:// doi.org/10.5054/tj.2010.220425

Al-Jamal, D. A., \& Al-Jamal, G. A. (2013). An investigation of the difficulties faced by EFL undergraduates in speaking skills. English Language Teaching, 7(1), 19.

Al Fadda, H. (2012). Difficulties in academic writing: From the perspective of King Saud University postgraduate students. English Language Teaching, 5(3), 123.

AlHashemi, B. I., AlSubaeie, M. S., \& Shukri, N. A. (2017). Academic writing needs of 
TESOL postgraduate students in the Saudi context. International Journal of English Language Education, 5(2), 151-163.

Boakye, N. A. (2017). Exploring students' reading profiles to guide a reading intervention programme. English Language Teaching, 10(7), 158. https:// doi.org/10.5539/elt.v10n7p158

Dhieb-Henia, N. (2003). Evaluating the effectiveness of metacognitive strategy training for reading research articles in an ESP context. English Specific Purposes, 22(4), 387-417. https:// doi.org/10.1016/S0889-4906(03)00017-6

Dornyei, Z. (2007). Research methods in applied linguistics.

Etikan, I., Musa, S. A., \& Alkassim, R. S. (2016). Comparison of convenience sampling and purposive sampling. American Journal of Theoretical and Applied Statistics, 5(1), 1-4.

https:// doi.org/10.11648/j.ajtas.20160501.11

Gönen, İ. K. (2015). The relationship between FL reading strategies and FL reading proficiency: A study on Turkish EFL learners. Educational Research and Reviews, 10(24), 2924. https:// doi.org/10.5897/ERR2015.2530

Lee, E., \& Lew, L. (2001). Diary studies: The voices of nonnative English speakers in a master of arts program in teaching English to speakers of other languages. CATESOL Journal, 13(1), 135-149.

Mahmood, H., \& Burke, D. (2018). Analysis of Acculturative Stress and Sociocultural Adaptation Among International Students at a Non-Metropolitan University. Journal of International Students, 8(1), 284-307.

Meniado, J. C. (2016). Metacognitive Reading Strategies, Motivation, and Reading Comprehension Performance of Saudi EFL Students. English Language Teaching, 9(3), 117-129. https:// doi.org/10.5539/elt.v9n3p117

Nation, I. S., \& Macalister, J. (2009). Language curriculum design: Routledge.

Phakiti, A., \& Li, L. (2011). General academic difficulties and reading and writing difficulties among Asian ESL postgraduate students in TESOL at an Australian university. Relc Journal, 42(3), 227-264. https://doi.org/10.1177/0033688211421417

Pittenger, K. K., Miller, M. C., \& Mott, J. (2004). Using real-world standards to enhance students' presentation skills. Business Communication Quarterly,67(3), 327-336. https://doi.org/10.1177/1080569904268084

Richards, J. C. (2001). Curriculum development in language teaching: Ernst Klett Sprachen.

Sawir, E. (2005). Language difficulties of international students in Australia: The effects of prior learning experience. International Education Journal, 6(5), 567-580.

Sukitkanaporn, T., \& Phoocharoensil, S. (2014). English presentation skills of Thai graduate students. English Language Teaching, 7(3), 91. https:// doi.org/10.5539/elt.v7n3p91 


\section{Macrothink}

International Journal of English Language Education

ISSN 2325-0887

2020, Vol. 8, No. 1

Turkpour, A., \& Mehdinezhad, V. (2016). Social and academic support and adaptation to college: Exploring the relationships between indicators' college students. International Education Studies, 9(12), 53-60. https:// doi.org/10.5539/ies.v9n12p53

Understand how to calculate your IELTS scores. (n.d.). Retrieved from https://takeielts.britishcouncil.org/find-out-about-results/understand-your-ielts-scores

Yu, T., \& Richardson, J. C. (2015). An exploratory factor analysis and reliability analysis of the Student Online Learning Readiness (SOLR) instrument. Online Learning, 19(5), 120-141.

Zhao, R., \& Hirvela, A. (2015). Undergraduate ESL students' engagement in academic reading and writing in learning to write a synthesis paper. Reading in a Foreign Language, 27(2), 219.

\section{Copyright Disclaimer}

Copyright for this article is retained by the author(s), with first publication rights granted to the journal.

This is an open-access article distributed under the terms and conditions of the Creative Commons Attribution license (http://creativecommons.org/licenses/by/3.0/). 